\title{
Research on the Choice between Fertility and Career Development under the Universal Two Child Policy during the Post-Industrial Erain China
}

\author{
Xiulan CHEN,ZhaominZOU* \\ School of Finance, Shanghai Lixin University of Accounting and Finance,Shanghai, China \\ *Corresponding Author
}

\begin{abstract}
With China's society entering the post-industrialera, the decline of fertility has become a serious issue for China's sustainable economic growth. After the implementation of the universal two-child policy, career women inChinaare confronted with the contradiction between fertility and career development. In this context, we choose career women as the research object, and investigate its fertility intention and its impact on career development. The research on this issue is not only aimed at the consequence of "the universal two-child" policy, but also seek to further explore whether the possible "universal three-child" or "fully liberalization of birth policy" will still encounter this problem. We investigated656 career women in Zhejiang Province and found that their choice of fertility was mainly affected by several characteristics, such as different age, family status, educational background, the nature of the work, exist significant difference. The results of the factor analysis model showed that there are four major factors as workplace development factor, family atmosphere factor, national policy factor, social environment factor which affectfertility intentions of the career women. Finally, logistic regression model was established using four factors are deeply analyzed the various factors, especially the career development factors on the influence of career women fertility intentions.
\end{abstract}

Keywords: Post-industrialization ; Universal two-child policy; Career women;Fertility intentions; Career development; Factor analysis; Logistic regression model

\section{Introduction}

The results of Chinese seventh national population census shows that the population in 2020 was $1,411.78$ million persons, increased by 72.06 million persons compared with the population of 1,339.72 million persons in 2010 (data of the Sixth National Population Census), up by 5.38 percent.In terms of age composition, there were 264.02 million persons in the age group of 60 and over, accounting for 13.50 percent. Of the national population, the sex ratio (female $=100$, male to female) was 105.07 , basically the same level with a slight decline compared with that in 2010. But the sex ratio at birth was 111.3, down by 6.8 compared with that in 2010. In terms of birth rate, the total fertility rate is 1.18 , which is lower than the generation replacement level of 2.1 , and also lower than the world average Level 2.5. The average annual growth rate of the birth rate between 2000 and 2010 was $0.57 \%$, which was half the average annual growth rate of $1.07 \%$ between 1990 and 2000. Even though China's total population stays always in highest level in the past 10 years, and the natural population growth rate went down to $3.34 \%$, the lowest level in the past 10 years. In conclusion, the fertility rate of Chinese population continues to fall, and the problem of aging population is becoming a serious challenge. The main issues of the population composition have changed from the overpopulation to the ultra-low fertility level, population aging, and imbalanced sex ratio at birth. In fact, China's fertility policy has already undergone some important adjustments. Since the one-child policy began to be strictly implemented in the 1980s, and some adjustments have been madein the past two decades. In 2013, the Third Plenary Session of the 18th Central Committee decided to implement the two-child fertility policy for couples where either the husband or the wife is from a single-child family. One year after the implementation of this policy, it was found that the expected results were not achieved. Subsequently, "the universal two-child policy" has been implemented on January 1, 2016. The adjustment of the population policy at this stage has a positive effect on raising the fertility level to better enhance the family's ability to resist risks, alleviating the process of population aging, and promoting sustainable economic and social development. However, if a family choose to have a second child, it may affect professional women. The best time for career development and childbearing is also the golden period for women's career development. Having a second child

ISSN: 0010-8189

(c) CONVERTER 2020

www.converter-magazine.info 
has a continuous impact on women's employment, promotion and lifelong development. In a fiercely competitive labor market, employers may consider cost-benefit issues and aggravate implicit gender discrimination in employment. Theuniversal two-child policy may become the "invisible threshold" for career promotionfor professional women. Although this policy further liberalizes birth restrictions, failure to complete the supporting measures system for the protection of the rights and interests of professional women will affect the expected effects of the policy. Is there a need for more liberalization of fertility policies in the future? After more liberalization, is it possible that it will still be difficult to achieve the goal of increasing fertility due to career development choices? The research on these issues needs to first explore the relationship between female childbearing willingness and workplace choices under the universal two-child policy, which is also the reason for the investigation and research of this article.

\section{Literature Review}

Regarding the definition of career women in China, it is generally considered that all women who participate in social and economic activities other than housework and get paid can be called career women. ${ }^{[1]}$ They are engaging in an activity for gain or as a means of livelihood. In our modern society, getting a joballows toearn an autonomous identity and seek financial independence. As a consequence, a career woman doesn't rely on herhusband or family member but earn their own living. Until now, most of the research about career women and their professional development still focus on the conflict between work and family. Because many career women are very performantin both sides and sometime, they have to make a choice between career development and familyresponsibility. The sustainable development of a modern society mainly depends on the stability of the family, and the mismatch of the family's internal relations will lead to social instability even chaos. That is why the problem of fertility of career women becomes a very important issue in the source of family instability ${ }^{[2]}$.

If work-family conflicts arise, it will produce a negative impact on employees' psychology and family stability, especially when professional women face the choice of work and family, they are susceptible to family atmosphere and other factors. ${ }^{[3-4]}$ Professional women not only have to undertake work outside the family, but also are the most important members in family life who are responsible for childbirth and raising children. Their dual identities make them face work-family conflicts that are more serious than those of men in the family. Mitigating the conflict between work and family requires self-regulation and external support. Among them, the support of the boss has a certain effect on alleviating the work-family conflict of professional women. ${ }^{[5]}$ There are also many researchers at home and abroad who have studied the work-family conflicts encountered by female employees of different occupational natures. For example: Ma Xiuling (2009) focused on the work-family conflicts of a specific group of female civil servants at the provincial and ministerial levels in party and government agencies. Research on the problem and believe that this factor has an impact on their career development; ${ }^{[6]}$ Tang Meiling (2011) specifically focused on the work-family conflict of young white-collar women; ${ }^{[7]}$ Muasya (2016) surveyed 375 Kenyans Female teachers in public schools come to study the work-family conflicts they face. ${ }^{[8]}$ These research conclusions are relatively consistent, and they basically agree that professional women have work-family conflicts, and this status quo affects their career development and subjective well-being. ${ }^{[9]}$ In addition, there are many studies on pregnant female employees who are affected by the working environment and workplace atmosphere, and also have a negative impact on the workplace or colleagues. ${ }^{[10-11]}$ Researchers found that women's pregnancy is easily treated negatively at work, or that pregnancy will affect their professional image. Therefore, some studies on the management of social identity impressions of professional women during pregnancy to help female employees during pregnancy Maintain its competitiveness and avoid affecting its career planning and development due to fertility issues. ${ }^{[12-14]}$ Before the implementation of the "universaltwo-child" birth policy, Ying Duo (2015) and Feng Yukun (2015) believed that the implementation of the policy would have an adverse impact on women's employment and career planning. It is necessary to increase the willingness of professional women to bear children. It is necessary for the government to provide policy support, legal protection, and recognition of the contribution of professional women to the family by the whole society; ${ }^{[15-16]}$ Lifen Kwong, Tongshun Cheng (2016) studied how to protect the basic rights of women under this policy from the perspective of gender justice. Including fair employment and professional development rights; ${ }^{[17]}$ Wang Zixuan (2016) studied how to improve the competitiveness of professional women under the universaltwo-child policy; ${ }^{[18]}$ Zhang Yun (2016) and Ou Peiwen

ISSN: 0010-8189

(C) CONVERTER 2020

www.converter-magazine.info 
(2016) found this policy through research The implementation of this policy implicitly increases the difficulty of women's employment and career advancement, and gender discrimination in employment may increase. The government needs to monitor and seek countermeasures to protect women's rights and interests. ${ }^{[19-20]}$ On the whole, the universaltwo-child policy provides policy support for families willing to give birth, but professional women are therefore faced with difficult choices in fertility and career development. "Fertility" or "promotion" is a hard choice to make by every professional woman of childbearing age who needs to comprehensively consider many factors. Which factors will affect fertility choices? How the fertility decision can be progressively affected by the promotion condition in professional competition?All these issues will be carefully studied in this article. Therefore, this paper analyzes these issues by constructing a logistic regression model based on factor analysis.

\section{Data description and analysis methods}

Based on the definition of previous scholars, the professional women defined in this article refer to the group of women who participate in social and economic activities and obtain a certain amount of labor compensation. The subjects of the survey are working women: civil servants, employees of public institutions, employees of enterprises, owners of private enterprises and other working women. The core question of the survey is "when faced with the conflict between career development and childbirth, what is your choice?" and the factors that influence this choice. The survey subjects include professional women who have given birth to one child and professional women who have not given birth. The original data used in this study comes from a sample survey of professional women's childbearing willingness and career development choices conducted by the practical team led by the author of this article from February 2019 to July 2020. From the 11 prefecture-level cities in Zhejiang Province, based on the comprehensive influence of economic development level, urbanization and other factors, we selected four representative cities (Hangzhou, Ningbo, Shaoxing, and Jiaxing) to conduct a survey of professional women. These four cities are the cities with better economic development in Zhejiang Province. The enterprises are more concentrated and the occupations of women are diversified. It is convenient to study the fertility willingness of women of different occupation types and the influence of the development of the workplace. A total of 656 professional women from Hangzhou, 208 from Ningbo, 127 from Shaoxing, and 88 from Jiaxing were selected for the survey. The random sampling method was adopted in the survey, and the survey respondents were mainly surveyed by questionnaires, supplemented by individual interviews and observation methods. Based on the acceptable error of less than 5\%, the survey decided to issue 710 questionnaires, and finally recovered 656 valid questionnaires, with an effective response rate of $92.4 \%$.

The data analysis methods used in this article are chi-square test, factor analysis, and binary logistic regression model analysis. The chi-square test is used to study whether professional women with different characteristics have significant differences in the choice of having a second child and career development. A factor analysis is constructed. The model summarizes the complex factors that affect choice into several independent composite influencing factors. On this basis, the logistic regression model is used to study how and to what extent these composite influencing factors have on fertility choices. Among these effects, what role does career development play? The data analysis tool is SPSS22.0 .

\section{IV.Survey result analysis}

\subsection{Overview of sample surveys}

As shown in Figure1, during the sampling of the basic information of the person filling in the questionnaire, the "age" is controlled within a relatively close range. Considering that the age of 26-40 years-old is the main stage of female career promotion, the age ratio is controlled at the proportion of women aged from 26 to 30 and the proportion of women aged 31-40 accounted for about 2/3 of the survey objects in order to make the conclusion more relevant. Most of the surveyed professional women have higher education degrees. Highschool and postgraduate degrees and above are less than the former two. The distribution of the surveyed degree is similar to the normal distribution, which is in line with the actual situation of society. In terms of status of the work unit, most of the professional women in Zhejiang Province are employed in private enterprises and state-owned

ISSN: 0010-8189

(C) CONVERTER 2020

www.converter-magazine.info 
enterprises. Compared with the former two, there are fewer professional women working in public institutions and other units. In terms of working years, professional women who have worked for more than 4 years account for a larger proportion of all respondents. In terms of family income, most of professional women's family annual revenuesdo not exceed 350,000RMB. Because the main purpose of our study is to evaluate the willingness of second childbirth and professional development of career women, those who are married and already have one child are the subject of our survey, and the selected sample accounts for more than $80 \%$ of all respondents.

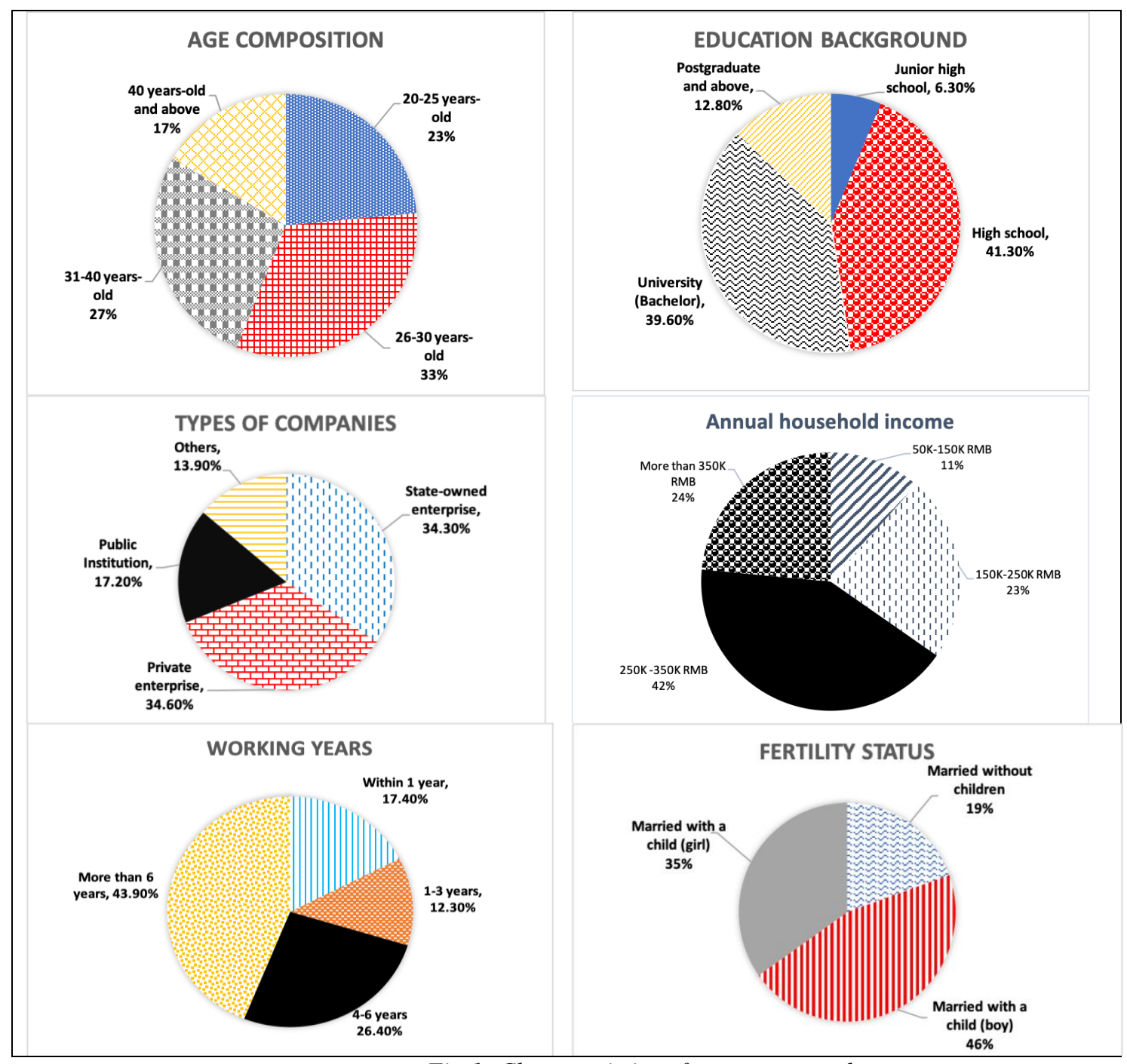

Fig.1: Characteristics of survey respondents

4.2Analysis of difference between childbearing willingness and career development choices of professional women in Zhejiang Province

As a career woman, choosing to have a second child means investing more energy in the family, and her professional contribution will be affected. Nowadays, in Chinese oversupply of labor market, having a second child will further increase the difficulty for women to find and maintain a job, and the further development of the workplace will be greatly affected. If a career woman voluntarily withdraws from the labor market and return to the family, they will lose their sense of self-worth due to unemployment status, and the total family income will be negatively impacted. Even if a woman does not completely withdraw from the labor market, the balance between family and career will result in insufficient energy and difficulty in achieving better development in the workplace. Therefore, despite of the "universal second-child policy", professional women

ISSN: 0010-8189

(C) CONVERTER 2020

www.converter-magazine.info 
still have to face a hard choice between career development and having a second child. From Table1 to7, theysummarize the choices made by professional women in different situations when they face the conflict between having a second child and their career development. Table8 explains whether professional women have significantly different choices in different situations.

Table1Choices between childbirth and career development of career women in different age groups

\begin{tabular}{|c|c|c|c|}
\hline & Childbirth & career development & total \\
\hline 20-25 years-old & 88 & 92 & 154 \\
\hline 26-30 years-old & 80 & 134 & 214 \\
\hline 31-40 years-old & 40 & 114 & 108 \\
\hline 40 years-old and above & 24 & 84 & 656 \\
\hline Total & 232 & 424 & 108 \\
\hline
\end{tabular}

Table2 Choices between childbirth and career development of career women with different educational backgrounds

\begin{tabular}{|c|c|c|c|}
\hline & Childbirth & Career development & Total \\
\hline Junior high school & 124 & 10 & 41 \\
\hline High school & 31 & 147 & 271 \\
\hline University (Bachelor) & 108 & 152 & 260 \\
\hline Postgraduate and above & 24 & 60 & 84 \\
\hline Total & 287 & 269 & 656 \\
\hline
\end{tabular}

Table 3 Choices between childbirth and career development of career women with different types of companies as their working place

\begin{tabular}{|c|c|c|c|}
\hline & Childbirth & Career development & Total \\
\hline State-owned enterprise & 40 & 187 & 227 \\
\hline Private enterprise & 80 & 145 & 225 \\
\hline Public Institution & 104 & 9 & 113 \\
\hline Others & 8 & 83 & 91 \\
\hline Total & 232 & 424 & 656 \\
\hline
\end{tabular}

Table4 Choices between childbirth and career development of career women with different working years

\begin{tabular}{|c|c|c|c|}
\hline & Childbirth & Career development & Total \\
\hline Within 1 year & 24 & 90 & 114 \\
\hline 1-3 years & 208 & 80 & 288 \\
\hline 4-6 years & 112 & 61 & 173 \\
\hline More than 6 years & 40 & 41 & 81 \\
\hline Total & 256 & 400 & 656 \\
\hline
\end{tabular}

Table 5 Choices between childbirth and career development of career women in different cities of Zhejiang Province

\begin{tabular}{|c|c|c|c|}
\hline & Childbirth & Career development & Total \\
\hline Shaoxing & 80 & 47 & 127 \\
\hline Jiaxing & 4 & 84 & 233 \\
\hline Hangzhou & 37 & 196 & 208 \\
\hline Ningbo & 111 & 97 & 656 \\
\hline Total & 232 & 424 & \\
\hline
\end{tabular}

Table 6 Choices between childbirth and career development of career women with different annual household

ISSN: 0010-8189

(C) CONVERTER 2020

www.converter-magazine.info 
income

\begin{tabular}{|c|c|c|c|}
\hline & Childbirth & Career development & Total \\
\hline 50K-150K RMB & 40 & 114 & 154 \\
\hline 150K-250K RMB & 116 & 158 & 274 \\
\hline 250K -350K RMB & 44 & 108 & 152 \\
\hline More than 350K RMB & 32 & 44 & 76 \\
\hline Total & 232 & 424 & 656 \\
\hline
\end{tabular}

Table7Choices between childbirth and career development of career women with different fertility status

\begin{tabular}{|c|c|c|c|}
\hline & Childbirth & Career development & Total \\
\hline Married without children & 40 & 88 & 128 \\
\hline Married with a child (boy) & 40 & 260 & 300 \\
\hline Married with a child (girl) & 152 & 76 & 228 \\
\hline Total & 232 & 424 & 656 \\
\hline
\end{tabular}

Table8 The Chi-Square Test Results of Various Influencing Factors and Professional Women's Choice

\begin{tabular}{|c|c|c|c|c|}
\hline Influencing factors & $\chi^{2}$ & df & $\begin{array}{c}\text { Progressive Sig. } \\
\text { (Both sides) }\end{array}$ & $\begin{array}{c}\text { significantly } \\
\text { related }\end{array}$ \\
\hline Age & 28.886 & 3 & 0.000 & Yes \\
\hline Education & 85.530 & 3 & 0.000 & Yes \\
\hline Work unit nature & 218.144 & 3 & 0.000 & Yes \\
\hline Working years & 141.896 & 3 & 0.000 & Yes \\
\hline Working location & 147.157 & 3 & 0.000 & Yes \\
\hline Annual Household Income & 16.015 & 3 & 0.001 & Yes \\
\hline Fertility status & 162.382 & 2 & 0.000 & Yes \\
\hline
\end{tabular}

The following conclusions can be drawn from the above tables:

(1) There are significant differences in the choice of professional women between "promotion" or "birth" among different age groups, and the factor of age has a significant impact on the choice of professional women. As shown in Table 1, career women between the ages of 26 and 40 tend to "promote" because they generally have senior positions and higher incomes than younger women, so they are more willing to stay in their current positionwith more expectations for promotion. If theysuspendtheir career development, theyprobably will not only loss their promotion opportunity, but also risk losingtheir job. The 20-25 years-old professional women tend to "give birth" mainly because younger women have just started their career. If they choose to have children, even if they lose their jobs, they will not have a serious impact. They can continue to enter the workplace in the future. Professional women over 40 years-old prefer "birth" because they generally have senior positions or better revenues, and then have less expectations for promotion, so they can choose childbearing conditions.

(2) Different education backgrounds of professional women can significantly affect the choice between career promotion and fertility intention. It is not difficult to conclude from Table 2 those professional women with lower education levels are more inclined to "fertility", and professional women with a postgraduate degree or above are more inclined to "career promotion". The main reason is that professional women with junior high school education have entered the society earlier, their career development prospects are generally not great, and the idea of having children is more deeply rooted than the realization of personal values. Therefore, professional women with junior high school education are more inclined to fertility. On the other hand, professional women with highereducation background pay more attention to their career developmentwith less willing to have second child.

(3) Professional women's different nature of work units can significantly affect the choice of between career development and fertility intention. Compared with private companies, state-owned enterprises and public institutions have relatively less competitive pressure, better welfare benefits, and low personnel mobility.

ISSN: 0010-8189

(C) CONVERTER 2020

www.converter-magazine.info 
Therefore, professional women working in state-owned enterprises or institutions are more inclined to have second child. On the other hand, state-owned enterprises and public institutions have more effective social protection policies for pregnant working women. According to the Law of the People's Republic of China on the Protection of Women's Rights and Interests, it is clearly stipulated that no companies are allow to dismiss women on the grounds of marriage, pregnancy, maternity leave, breastfeeding, etc. The employee or unilaterally terminates the labor contract. According to Table 3, it can be seen those professional women working in private enterprises may choose to "promotion" and give up "fertility" for higher pursuits and career planning. Therefore, professional women in state-owned enterprises and public institutions have more willing to have children.

(4) Different working years of professional women can significantly affect the choice between career development and fertility intention. Table 4 shows that professional women with 1-3 years are more inclined to have children. For those who have just started to work, they generally pay more attention to career promotion. However, professional women who have worked for 4-6 years prefer promotion. And those who have worked for more than 6 years want to keep the balance between "promotion" and "fertility" The reason is also obvious. Women who have just stepped into the work environment are willing to sacrifice their own life in order to better adapt to the work process. And when professional women have been working for 4-6 years, their career prospects and work-related goals become easily achievable. In this case, they have stronger willing to promotion than fertility.

(5) Different working locations of professional women affect significantly the choice of career development and fertility intentions. Compared with other basic situations, regional differences are a secondary factor in the choice of fertility among professional women. Professional women working in big city like Hangzhou are more inclined to "promotion", while professional women in small cities like Shaoxing, Jiaxing, and Ningbo are relatively less inclined to "promotion". This phenomenon may be explained local customs and culture.

(6) Different family incomes of professional women can significantly affect their choice of career development and fertility intention. Professional women with higher family income will choose to promotion. Because the high income may be related to higher professional positions or better working conditions, the opportunity cost of development is too high to support, so they have to choose career promotion. On the contrary, most of the professional women in families with medium annual income will choose to have more children because of lower opportunity cost related to their professional position.

(7) Different fertility status of professional women can significantly affect their choice of career development and fertility intention. It can be clearly seen from Table 7 those professional women who are married but have no child and who have a boy tend to choose promotion, while those who have given birth to a girl prefer to fertility. From the content of the interviews and related data, it is found that for professional women who are married but have not given birth to children, they are in the early stages of their careers, and having children will have a great impact on their future career development, while those who are married and have given birth to a boy have less willing of having a second child. After traditional women's so-called task of inheriting the family, career prospects become their priority. Because most families still have a patriarchal mentality, professional women in this type of family face more pressure to have a second child.

4.3 Analysis of factors that contribute to career women's choice between fertility and promotion in Zhejiang Province

Based on the above analysis, it can be seen that the factors that affect professional women's choice between "promotion" or "fertility" in the context of "universal second-child policy" are numerous and complicated. The choices of professional women in different situations have significant differences. In order to further analyze the influencing factors of female fertility choices, we use factor analysis method to simplify the further processing of the selected 21 influencing factors.

\subsubsection{Reliability and validity test}

ISSN: 0010-8189

(C) CONVERTER 2020

www.converter-magazine.info 
Reliability testing refers to whether the test results are stable and reliable. In this survey, Cronbach's $\alpha$ coefficient was used for reliability test. Generally speaking, a Cronbach $\alpha$ coefficient above 0.65 is the minimum acceptable reliability value. The overall Cronbach $\alpha$ coefficient of the professional women's career development and fertility scale in the questionnaire is 0.843 , and the Cronbach $\alpha$ coefficients of each item in the interpersonal relationship scale in the formal questionnaire are all greater than 0.65 , which belongs to a very reliable interval range, and the reliability test passes. Validity test is to judge whether it is suitable for factor analysis through KMO and Bartlett sphericity test before analyzing the factor results. The results are shown in Table 9:

Table9KMO\&Bartlett's test of sphericity

\begin{tabular}{|l|l|r|}
\hline Kaiser-Meyer-Olkin & & 0.88 \\
\hline Bartlett's test of sphericity & Chi-squared & 27468.55 \\
\hline & df & 210 \\
\hline & Sig. & 0.000 \\
\hline
\end{tabular}

The KMO test is based on the comparison of simple correlations and partial correlations between variables. The larger the KMO value, the more suitable for factor analysis. It is generally believed that if KMO $>0.9$, it is very suitable for factor analysis; $\mathrm{KMO}>0.7$ is more suitable; $\mathrm{KMO}<0.5$, the data obtained is not suitable for factor analysis. The KMO value in the survey data is 0.88 , which is greater than 0.70 at this time, and the effect of factor analysis is better. The Bartlett sphere test is used to test whether the correlation matrix is an identity matrix, that is, whether each variable is independent. When the confidence level is $95 \%$, the probability value of the significance test is $0.000<0.05$, and the null hypothesis is rejected, indicating that it is suitable for factor analysis.

\subsubsection{Factor analysis}

There are many factors influencing career women's choice to have a second child or their career development, and the relationship between these factors is complicated. According to the above KMO and Bartlett sphericity test, it has been confirmed that the factors have a strong correlation, so they can be summarized into several It is more appropriate to study a representative and independent factor. This paper uses factor models to extract factors from the 21 main influencing factors that affect the choice of professional women, and find several influencing factors that reflect some common characteristics from many indicators. The mathematical model is: assuming that there are $\mathrm{n}$ main factors that affect the choice of professional women, ..., through factor analysis, these $\mathrm{n}$ primitive variables are expressed as $\mathrm{k}$ public factors $(, \ldots)()$ and a special factor linear The weighted sum, where the common factors, ,... are pairwise orthogonal, and they are independent of the special factors, so that each factor can reflect the common information of multiple variables in the same group to the greatest extent:

$$
X_{i}=\alpha_{i 1} f_{1}+\alpha_{i 2} f_{2}+\ldots \ldots+\alpha_{i k} f_{k}, \quad i=1,2 \ldots \ldots n_{(1)}
$$

Its matrix expression is:

$$
\left[\begin{array}{c}
X_{1} \\
X_{2} \\
\cdots \\
X_{n}
\end{array}\right]=\left[\begin{array}{cccc}
\alpha_{11} & \alpha_{12} & \ldots & \alpha_{1 k} \\
\alpha_{21} & \alpha_{22} & \ldots & \alpha_{2 k} \\
\ldots & \ldots & \ldots & \ldots \\
\alpha_{n 1} & \alpha_{n 2} & & \alpha_{n k}
\end{array}\right]\left[\begin{array}{c}
f_{1} \\
f_{2} \\
\ldots \\
f_{k}
\end{array}\right]+\left[\begin{array}{c}
\varepsilon_{1} \\
\varepsilon_{2} \\
\cdots \\
\varepsilon_{n}
\end{array}\right]_{(2)}
$$

It can be seen from the model that the data of the original variables are obtained through investigation. The $\mathrm{k}$ common factors and special factors are unobservable latent variables. The common factors reflect some common characteristics of the variables. The coefficient matrix in the model is the factor loading matrix, reflecting the correlation between the common factor and the original variable, the larger the absolute value, the higher the closeness of the correlation. According to the above model, this paper uses the principal component method to extract common factors, uses the maximum variance method and orthogonally rotates the original factor loading matrix to obtain Table 11. According to the factor extraction criteria with eigenvalues greater than 1, four principal factors are extracted as shown in Table 10.

ISSN: 0010-8189 
Table10 Total Variance Explained

\begin{tabular}{|c|c|c|c|c|c|c|c|c|c|}
\hline \multirow{2}{*}{ Component } & \multicolumn{4}{|c|}{ Initial Eigenvalues } & \multicolumn{3}{c|}{ Extraction Sums of Squared } & \multicolumn{3}{c|}{$\begin{array}{c}\text { Rotation Sums of } \\
\text { Loading }\end{array}$} \\
\cline { 2 - 12 } & Total & $\begin{array}{c}\text { \% of } \\
\text { Variance }\end{array}$ & $\begin{array}{c}\text { Cumulative } \\
\%\end{array}$ & Total & $\begin{array}{c}\% \text { of } \\
\text { Variance }\end{array}$ & $\begin{array}{c}\text { Cumulativ } \\
\text { e }\end{array}$ & Total & $\begin{array}{c}\text { Cumulative } \\
\%\end{array}$ & Total \\
\hline 1 & 7.878 & 37.514 & 37.514 & 7.878 & 37.514 & 37.514 & 7.641 & 36.388 & 36.388 \\
\hline 2 & 5.637 & 26.843 & 64.357 & 5.637 & 26.843 & 64.357 & 5.711 & 27.197 & 63.585 \\
\hline 3 & 3.481 & 16.578 & 80.936 & 3.481 & 16.578 & 80.936 & 3.633 & 17.298 & 80.882 \\
\hline 4 & 2.692 & 12.818 & 93.754 & 2.692 & 12.818 & 93.754 & 2.703 & 12.871 & 93.754 \\
\hline
\end{tabular}

Table11 Rotated Component Matrix

\begin{tabular}{|c|c|c|c|c|c|}
\hline & & 1 & 2 & 3 & 4 \\
\hline$X_{1}$ & Are you satisfied with your current job? & 0.975 & -0.022 & -0.021 & 0.005 \\
\hline$X_{2}$ & Are you satisfied with your current income? & 0.974 & -0.051 & -0.019 & -0.023 \\
\hline$X_{3}$ & $\begin{array}{c}\text { Does your working atmosphere make you } \\
\text { feel comfortable? }\end{array}$ & 0.968 & -0.120 & -0.090 & -0.023 \\
\hline$X_{4}$ & $\begin{array}{c}\text { Do your superiors have no prejudice against } \\
\text { women? }\end{array}$ & 0.982 & -0.031 & -0.020 & -0.023 \\
\hline$X_{5}$ & Are you in a key position in your company? & 0.975 & -0.021 & -0.021 & -0.023 \\
\hline$X_{6}$ & Are you passionate about your job? & 0.982 & -0.031 & -0.020 & -0.023 \\
\hline$X_{7}$ & Do you have great career ambition? & 0.975 & -0.019 & -0.059 & 0.062 \\
\hline$X_{8}$ & $\begin{array}{c}\text { Do you want to stay in this company until } \\
\text { retirement? }\end{array}$ & 0.975 & -0.021 & -0.021 & -0.023 \\
\hline$X_{9}$ & $\begin{array}{l}\text { Do your parents encourage you to have } \\
\text { more children? }\end{array}$ & -0.052 & 0.988 & 0.064 & 0.001 \\
\hline$X_{10}$ & $\begin{array}{l}\text { Does your husband want to have a second } \\
\text { child? }\end{array}$ & -0.052 & 0.988 & 0.064 & 0.001 \\
\hline$X_{11}$ & Are you in good health? & -0.063 & 0.947 & -0.034 & -0.012 \\
\hline$X_{12}$ & $\begin{array}{c}\text { Do you have a very good family } \\
\text { relationship? }\end{array}$ & 0.019 & 0.941 & 0.097 & -0.009 \\
\hline$X_{13}$ & $\begin{array}{c}\text { Do you have absolute right to speak in your } \\
\text { family? }\end{array}$ & -0.058 & 0.986 & 0.060 & 0.004 \\
\hline$X_{14}$ & $\begin{array}{l}\text { Does your first child want to have a little } \\
\text { brother or sister? }\end{array}$ & -0.051 & 0.983 & 0.061 & -0.018 \\
\hline$X_{15}$ & $\begin{array}{l}\text { Does the universal second-child policy } \\
\text { affect your childbirth choice? }\end{array}$ & -0.049 & 0.073 & 0.971 & 0.024 \\
\hline$X_{16}$ & $\begin{array}{c}\text { Do Chinese policies ensure enough } \\
\text { protective measures for career women after } \\
\text { pregnancy? }\end{array}$ & -0.043 & 0.060 & 0.944 & 0.034 \\
\hline$X_{17}$ & $\begin{array}{l}\text { Does the universal second-child policy } \\
\text { contributeto reducethe discrimination } \\
\text { against career women? }\end{array}$ & -0.044 & 0.063 & 0.948 & 0.031 \\
\hline$X_{18}$ & $\begin{array}{l}\text { Does the universal second-child policy } \\
\text { contribute to the promotion of women's } \\
\text { status in the workplace }\end{array}$ & -0.040 & 0.052 & 0.927 & -0.045 \\
\hline$X_{19}$ & $\begin{array}{c}\text { Does China's traditional concept of fertility } \\
\text { affect female fertility intention? }\end{array}$ & -0.018 & -0.001 & 0.013 & 0.949 \\
\hline$X_{20}$ & $\begin{array}{l}\text { Does current Chinese social environment } \\
\text { encourage women's career development? }\end{array}$ & -0.015 & 0.015 & 0.004 & 0.948 \\
\hline
\end{tabular}

ISSN: 0010-8189

(C) CONVERTER 2020 


\begin{tabular}{|c|c|c|c|c|c|}
\hline$X_{21}$ & $\begin{array}{c}\text { Does Chinese society gradually attach more } \\
\text { and more importanceto the prospects for } \\
\text { career advancement of women? }\end{array}$ & -0.010 & -0.040 & 0.021 & 0.944 \\
\hline
\end{tabular}

As shown in Tables10 and11, when the four principal component factors are extracted, the cumulative variance contribution rate is $93.754 \%$, which meets the requirement that the extraction factor variance is greater than $80 \%$. Using the extraction factor score to analyze the influencing factors of career development and fertility of professional women in Zhejiang Province, the comprehensive evaluation model is obtained:

$$
f=\frac{36.388}{93.754} f_{1}+\frac{27.197}{93.754} f_{2}+\frac{17.298}{93.754} f_{3}+\frac{12.871}{93.754} f_{4}
$$

Each factor has a large load on different variables, focusing on different specific angles: Factor 1 has a large load on the eight components of the variable, so it is named the workplace development factor; factor 2 is on the six variables There is a large load on the component, so it is named as the family atmosphere factor; factor 3 has a large load on the five components of the variable, and these factors are mainly the universaltwo-child policy, so it is named as the national policy factor ; Factor 4 has a relatively large load on the three components of the variables, so it is named the social environmental factor. Where the factor score matrix in formula (2):

$$
\left[\begin{array}{cccc}
\alpha_{11} & \alpha_{12} & \ldots & \alpha_{1 k} \\
\alpha_{21} & \alpha_{22} & \ldots & \alpha_{2 k} \\
\cdots & \cdots & \ldots & \cdots \\
\alpha_{n 1} & \alpha_{n 2} & & \alpha_{n k}
\end{array}\right]_{\text {the specific values are shown in Table12 }}
$$

\begin{tabular}{|c|c|c|c|c|}
\hline & factor 1 & factor2 & factor3 & factor4 \\
\hline Are you satisfied with your current job? & 0.129 & 0.008 & 0.008 & 0.007 \\
\hline $\begin{array}{l}\text { Are you satisfied with your current } \\
\text { income? }\end{array}$ & 0.128 & 0.003 & 0.010 & -0.004 \\
\hline $\begin{array}{l}\text { Does your working atmosphere make you } \\
\text { feel comfortable? }\end{array}$ & 0.126 & -0.008 & -0.008 & -0.003 \\
\hline $\begin{array}{l}\text { Do your superiors have no prejudice } \\
\text { against women? }\end{array}$ & 0.129 & 0.007 & 0.009 & -0.003 \\
\hline $\begin{array}{l}\text { Are you in a key position in your } \\
\text { company? }\end{array}$ & 0.129 & 0.008 & 0.009 & -0.003 \\
\hline Are you passionate about your job? & 0.129 & 0.007 & 0.009 & -0.003 \\
\hline Do you have great career ambition? & 0.129 & 0.010 & -0.003 & 0.029 \\
\hline $\begin{array}{l}\text { Do you want to stay in this company until } \\
\text { retirement? }\end{array}$ & 0.129 & 0.008 & 0.009 & -0.003 \\
\hline $\begin{array}{l}\text { Do your parents encourage you to have } \\
\text { more children? }\end{array}$ & 0.006 & 0.174 & -0.008 & 0.004 \\
\hline $\begin{array}{l}\text { Does your husband want to have a second } \\
\text { child? }\end{array}$ & 0.006 & 0.174 & -0.008 & 0.004 \\
\hline Are you in good health? & 0.002 & 0.169 & -0.035 & 0.000 \\
\hline $\begin{array}{c}\text { Do you have a very good family } \\
\text { relationship? }\end{array}$ & 0.015 & 0.166 & 0.003 & 0.000 \\
\hline $\begin{array}{l}\text { Do you have absolute right to speak in } \\
\text { your family? }\end{array}$ & 0.005 & 0.174 & -0.010 & 0.005 \\
\hline
\end{tabular}

Table12 Factor score coefficient matrix

ISSN: 0010-8189 
CONVERTER MAGAZINE

Volume 2021, No. 3

\begin{tabular}{|c|c|c|c|c|}
\hline $\begin{array}{c}\text { Does your first child want to have a little } \\
\text { brother or sister? }\end{array}$ & 0.006 & 0.174 & -0.009 & -0.003 \\
\hline $\begin{array}{c}\text { Does the universal second-child policy } \\
\text { affect your childbirth choice? }\end{array}$ & 0.008 & -0.012 & 0.270 & 0.001 \\
\hline $\begin{array}{c}\text { Do Chinese policies ensure enough } \\
\text { protective measures for career women after } \\
\text { pregnancy? }\end{array}$ & 0.009 & -0.014 & 0.263 & 0.005 \\
\hline $\begin{array}{c}\text { Does the universal second-child policy } \\
\text { contribute to reduce the discrimination } \\
\text { against career women? }\end{array}$ & 0.008 & -0.014 & 0.264 & 0.004 \\
\hline $\begin{array}{c}\text { Does the universal second-child policy } \\
\text { contribute to the promotion of women's } \\
\text { status in the workplace }\end{array}$ & 0.008 & -0.015 & 0.259 & -0.024 \\
\hline $\begin{array}{c}\text { Does China's traditional concept of } \\
\text { fertility affect female fertility intention? }\end{array}$ & 0.003 & 0.004 & -0.004 & 0.351 \\
\hline $\begin{array}{c}\text { Does current Chinese social environment } \\
\text { encourage women's career development? }\end{array}$ & 0.003 & 0.007 & -0.007 & 0.351 \\
\hline $\begin{array}{c}\text { Does Chinese society gradually attach } \\
\text { more and more importanceto the prospects } \\
\text { for career advancement of women? }\end{array}$ & 0.003 & -0.004 & -0.001 & 0.349 \\
\hline
\end{tabular}

\subsection{Empirical test}

In the above factor analysis, many influencing factors can be regrouped. Then we use four major factors to construct a logistic regression model, as shown below :

$$
\text { choose }_{i}=\ln \left(\frac{p}{1-p}\right)=\beta_{0}+\beta_{1} f_{1}+\beta_{2} f_{2}+\beta_{3} f_{3}+\beta_{4} f_{4}+\varepsilon
$$

Among them, the explained variables are professional women's willingness to have a second child ( choose $=1$ ) and career development(unwilling to have a second child, $c h o o s e=0$. According to the previous analysis, the explanatory variables are four factors, $f_{1}$ is the career development factor, $f_{2}$ is the family atmosphere factor, $f_{3}$ is the national policy factor, $f_{4}$ is the social environment factor, and $\varepsilon$ is the random error term.

Table13 Analysis Results

\begin{tabular}{|r|r|r|r|r|}
\hline & $(1)$ & $(2)$ & $(3)$ & $(4)$ \\
\hline$f_{1}$ & $-0.142^{*}$ & $-0.145^{*}$ & $-0.146^{*}$ & $-0.141^{*}$ \\
\hline$f_{2}$ & & $0.261^{*}$ & $0.268^{* * *}$ & $0.281^{* * *}$ \\
\hline$f_{3}$ & & & $-0.202^{* *}$ & $-0.213^{* *}$ \\
\hline$f_{4}$ & & & & $-0.431^{* * *}$ \\
\hline Constant term & $0.605^{* * *}$ & $0.609 * * *$ & $0.616^{* * *}$ & $0.629 * * *$ \\
\hline$R^{2}$ & 0.799 & 0.802 & 0.810 & 0.871 \\
\hline
\end{tabular}

Note: *, **, *** Respectively represent the significance level as $10 \%, 5 \%, 1 \%$ 。

According to Table 13, the regression results of each influencing factor are very significant. In other words, all

ISSN: 0010-8189

(C) CONVERTER 2020 
these factors have an important impact on the fertility choice of professional women. There is a contradiction between career development and fertility intention. The pursuit of career development is an obstacle to whether professional women choose to have a second child. As shown in the table above, with the introduction of other factors, the coefficient of is always negative and the difference is small, indicating that the inverse relationship between the two is robust, and women with better career development have lower willingness to bear children. In addition, family atmosphere factors have a positive and significant impact on the willingness to have a second child. Generally speaking, family support is also an important factor for professional women to choose to have a second child. It is generally believed that government policies will promote the willingness of professional women to bear children. However, in this result, it is found that national policy factors play a negative role. Although national policies provide corresponding protection measures for professional women to give birth to a second child, they may be due to these policy measures. It has not changed the implicit employment discrimination or substantially and implicitly affected the career promotion of women in the workplace, so it did not play a positive role. And if the social environment encourages women's career development, it is in line with reality for women in the workplace to choose career development instead of having a second child. The regression results of the model of professional women's willingness to have a second child with all the factors are as follows. The formula can be used to predict whether professional women choose to have a second child. The prediction accuracy rate of the calculation using this formula in this study is $91.3 \%$. It means that the formula used to predict the willingness to give birth to the second child of professional women is relatively reliable:

$$
p=\frac{e^{0.629-0.141 f_{1}+0.281 f_{2}-0.213 f_{3}-0.431 f_{4}}}{1+e^{0.629-0.141 f_{1}+0.281 f_{2}-0.213 f_{3}-0.431 f_{4}}}
$$

\section{Conclusions and Recommendations}

With the profound changes in social environment, the fertility level of Chinese families tends to decrease rapidly just like in developed countries. The universal two-child policy has been implemented since 2016, and the population has grown to a certain extent. However, as the main force of fertility, the professional women have to face the conflict between having a second child and their own career development. This article studies this issue through actual investigations and draws the following conclusions:

(1) The survey results show that professional women's ages, educational background, fertility status, nature of work, working years, working location, and annual family income can significantly affect their choices between "fertility" and "promotion". In other words, all these factors have a significant impact on their willingness of fertility.

(2) Because there are so many factors that affect the willingness to have a second child specially for career women, the model is constructed to perform factor analysis and summarized into four major factors: career development factor, family atmosphere factor, national policy factor, and social environment factor. Among them, the workplace development factor has the greatest impact on the second child's willingness to have a second child. Professional women are most concerned about the impact on their future career development before choosing to have a second child, and then consider the impact of other factors.

(3) After using the four factors as independent variables to perform logistic regression model, it is concluded that women who are well-developed in the workplace are less willing to have a second child. If fertility problems affect their career development, they are more inclined to give up having a second child.

Based on the above conclusions, in order to stabilize China's female fertility level after the universal two-child policy, the following suggestions are put forward:

(1) Improve the national maternity protection system to ensure the rights and interests of professional women. After the adoption of universal two-child policy, because of concerns about the impact that hiring women who

ISSN: 0010-8189

(C) CONVERTER 2020

www.converter-magazine.info 
undertake population reproduction may have negative impact on work efficiency, employers' intention to hire female employees may decrease, and women may encounter hidden employment discrimination when they first enter the workplace. And women who are already working in the workplace may also affect their promotion because of having a second child. Therefore, the government must first protect women's employment rights in accordance with the law, strictly implement laws and regulations such as the Labor Law of the People's Republic of China, the Law on the Protection of Women's Rights and Interests, and strictly punish companies that discriminate against sex and increase the cost of sex discrimination for companies. In the survey, it was found that professional women in state-owned enterprises and institutions are more willing to choose childbirth, mainly because the legal rights and interests of women in these institutions are better protected, and women's employment and leave rights and the retention of jobs after childbirth can be guaranteed. Second, improve the tax system that encourages companies to hire women, such as introducing relevant tax reduction and exemption policies or other measures to encourage employers to hire women. Finally, employers are encouraged to help female employees make career planning, so that they can better balance career planning and family in their career development, and make better use of the advantages of women, and they will not affect career promotion due to childbirth. Female employees should also try their best Balance your own strengths to your job position.

(2) Family members should create a harmonious atmosphere and care about professional women

How family members face this policy is a key factor that affects the choice of professional women. Through interviews with professional women or families with professional women, it is found that the willingness of professional women to have a second child is closely related to the family atmosphere, and family atmosphere supporting childbearing has a positive effect on the professional women's willingness to bear children. Therefore, under the full implementation of the universaltwo-child policy, family members should actively ask professional women for their opinions. If professional women have the desire to have children, they should provide them with spiritual and material support.

(3) Strengthen the social supervision mechanism and maintain the status of career women

The society needs to jointly monitor the implementation of the country's employment anti-discrimination law, because female employment is not only related to family harmony and stability, but also related to social and political stability. It is the responsibility of the entire society to safeguard women's labor rights and to ensure the balance between women and their work units. We must not refuse to hire or promote women because of women's reproductive behavior, which hinders women's career development. The employment anti-discrimination policy is an important guarantee for women's employment rights. Equal employment is advocated. The society should form a fair and just attitude towards the career development of professional women, and supervise employers' protection of women's reproductive rights and workplace development rights.In addition to the support provided by the government, society, and families for the childbirth of professional women, professional women themselves should also formulate career plans to enhance their professional competitiveness, and properly handle the contradiction between family and work during the process of giving birth to a second child. In addition, it is necessary to strengthen the awareness of rights protection and protect their reasonable rights and interests from infringement. Only when all aspects are properly arranged can the country's universaltwo-child policy have a good implementation effect.

\section{Acknowledgements}

This research was supported by Young Teacher Training Program Fund for Shanghai MunicipalUniversities.

\section{References}

[1] Zhu Chuzhu, Peng Xizhe. Women's participation in the journey. Beijing: Higher Education Press, 1996.

[2] Astoyants, Margaret S; Kovalev, Vitaly V;Davljatova, Svetlana V. Family Dysfunctions and Ways of Their Overcoming by Means of Social Work.International Journal of Environmental and Science Education, vol. 11, no. 7, pp.1451-1468, 2016.

ISSN: 0010-8189

(C) CONVERTER 2020

www.converter-magazine.info 
[3]. Aryee,S.; Leung, A.Role Stress or Inter Role Conflict,and Well-being:The Moderating Influence of Spoursal Support and Coping Behaviors among Employer Parents in Hong Kong. Journal of Vocational Behavior, vol. 54, pp. 259-278, 1999.

[4] Huffman, Ann Hergatt; Matthews, Russell A.;Irving, Louis H.Family fairness and cohesion in marital dyads: Mediating processes between work-family conflict and couple psychological distress.Journal of Occupational and Organizational Psychology. vol. 90, no. 1, pp.95-116, 2017.

[5] Zhang Li, Zhang Lin, Karen Korabik. Work-family conflicts among professional women-the moderating effect of work autonomy and supervisor support.Industrial Engineering and Management, vol. 15, no. 5,pp.87-90, 2010.

[6] Ma Xiuling.Research on the Growth Path and Career Development of Female Provincial and Ministerial Civil Servants in China's Party and Government Departments.Journal of National School of Administration, vol. 6, pp.94-98, 2009.

[7] Tang Meiling. Research on the "work-family" conflict of young white-collar women. Xiamen: Xiamen University Press, 2011.

[8] Muasya, Gladys.Is Work-Family Balance a Possibility? The Case of Kenyan Female Teachers in Urban Public Schools.International Journal of Educational Administration and Policy Studies, vol. 8, no. 5, pp.37-47, 2016.

[9] Hong Yanping, Lu Huixing, Yan Baojun. Work-family conflict of professional women and its relationship with social support and subjective well-being. Profession and Health, vol. 2,pp.402-405, 2013.

[10] Gueutal, H. G.; Taylor, E. M. Employee pregnancy: the impact on organizations, pregnant employees and co-workers. Journal of Business and Psychology, vol. 5, pp.459-476, 1991.

[11] Borve, Hege Eggen.Pregnant Bodies: Norwegian Female Employees in Global Working Life.European Journal of Women's Studies, vol. 14, no. 4, pp.311-326, 2007.

[12] Halpert, J. A.;Wilson, M. L.; Hickman, J. L.Pregnancy as a source of bias in performance appraisals.Journal of Organizational Behavior, vol. 14, pp.649-663, 1993.

[13] Hebl, M. R.;King, E. B.; Glick, P.; Singletary, S. L.;Kazama, S. Hostile and benevolent reactions toward pregnant women: Complementary interpersonal punishments and rewards that maintain traditional roles. Journal of Applied Psychology,vol. 92, pp.1499 -1511, 2007.

[14] Little, Laura M.; Smith Major, Virginia; Hinojosa, Amanda S.; Nelson, Debra L.professional image maintenance:how women navigate pregnancy in the workplace.Academy of Management Journal. vol. 58, no. 1, pp.8-37, 2015.

[15] Ying Duo. The universal second child policy: How to make "Soft Landing" of Women's Employment . Employment in China,vol. 12, pp.10-11, 2015.

[16] Feng Yukun. The universalsecond child policy: Is it more difficult for women to find jobs? Labor Security World, vol. 31, pp.35-35, 2015.

[17] Kuang Lifen, Cheng Tongshun. Guarantee of Women's Basic Rights under the "Universal Two-Child" Birth Policy_ — Based on the Perspective of Gender Justice.Journal of Tianjin Administration Institute, vol. 18, no. 04, pp.63-68, 2016.

[18] Wang Zixuan. The improvement of professional women's human resources quality under the universaltwo-child policy.Literary Education, vol. 07, pp.190,2016.

[19] Zhang Yun.The influence of the "universal two-child" policy on women's career development and its countermeasures.Journal of Fujian School of Administration, vol. 04, pp.104-111, 2016

[20] Ou Peiwen. The full implementation of the second-child policy will affect women's employment.Urban Society, vol. 34, pp.88-89, 2016. 